\title{
DOES THE PERMANENT CREEP-RATE OF POLYGRYSTALLINE ICE INCREASE WITH CRYSTAL SIZE?
}

\author{
By Paul Duval and Hugues Le GaG
}

(Laboratoire de Glaciologie du C.N.R.S., B.P. 53, 3804I Grenoble Cedex, France)

\begin{abstract}
Uniaxial compression creep tests were performed on artificial and natural polycrystalline ices at temperatures near $-7^{\circ} \mathrm{C}$. The grain-size range investigated was from $\mathrm{I}$ to $10 \mathrm{~mm}$. Contrary to previous results, the permanent creep-rate was not found to increase with crystal size. Only the transient creep appears to be sensitive to variations in crystal size.

RÉsumé. La vitesse du fluage stationnaire de la glace polycristalline croît elle avec la taille des cristaux? Des expériences de fluage en compression uniaxiale ont été réalisées sur des glaces polycristallines artificielles et naturelles aux températures voisines de $-7^{\circ} \mathrm{C}$. La taille des grains variait entre I et ro mm. A l'opposé des résultats récemment publiés, il est montré que la vitesse du fluage stationnaire ne croît pas avec la taille des cristaux. Seulement le fluage transitoire apparait être influencé par des variations de la taille des cristaux.

Zusammenfassung. Nimmt die ständige Kriechgeschwindigkeit polykristallinen Eises mit der Kristallgrösse zu? Mit künstlichen und natürlichen polykristallinem Eis wurden Kriechversuche unter einachsigem Druck bei Temperaturen um $-7^{\circ} \mathrm{C}$ durchgeführt. Der Korngrössenbereich lag zwischen I und Io mm. Im Gegensatz zu früheren Ergebnissen konnte keine Zunahme der ständigen Kriechgeschwindigkeit mit der Korngrösse festgestellt werden. Nur vorübergehendes Kriechen scheint von Änderungen der Kristallgrösse abzuhängen.
\end{abstract}

\section{INTRODUCTION}

In order to develop theoretical models for the flow of ice masses, it is necessary to know the constitutive law for the non-elastic deformation of polycrystalline ice. Laboratory creep tests are the tests most frequently performed. The important factors in the steady creep equation are deviatoric stresses $\tau_{i j}{ }^{\prime}$ and temperature $T$, which appear in the form:

$$
\dot{\epsilon}_{i j}=\tau_{i j^{\prime}} / 2 \eta=\frac{B^{\prime}}{2} \tau^{n-1} \tau_{i j^{\prime}} \exp (-Q / R T),
$$

where $\dot{\epsilon}_{i j}$ are strain-rates, $\eta$ the viscosity, $B^{\prime}$ a constant, $Q$ the activation energy for creep, $R$ the gas constant, and $\tau$ the effective shear stress defined by $\tau^{2}=\frac{1}{2} \sum_{i j}\left(\tau_{i j}{ }^{\prime}\right)^{2}$. Equation (I) has been verified by Duval ([1977]) with creep tests performed in torsion, compression, and torsion-compression. The exponent $n$ is about three at least over the stress range o. I $\mathrm{MN} \mathrm{m}^{-2}<\tau<0.5 \mathrm{MN} \mathrm{m}^{-2}$.

For low stresses, it seems that the exponent $n$ is smaller than 3 (Mellor and Testa, I969; Colbeck and Evans, 1973; Duval, I973). These results support the idea that two distinct mechanisms are controlling the deformation of ice for low and high stresses. From the deformation map given by Goodman (1978), the linear flow corresponding to NabarroHerring diffusional creep could be observed for stresses of the order of $0.1 \mathrm{MN} \mathrm{m}^{-2}$ but with grain-sizes below I mm.

For high stresses, creep-rate could be controlled either by recovery processes (Duval, [1977]) or by dislocation glide (Goodman, unpublished). Recent studies by Baker (1978) have showed that steady creep was very sensitive to variations in ice-crystal size. Increasing or decreasing the average crystal size from a value of about $\mathrm{I} \mathrm{mm}$ results in an increase in secondary creep-rate. From Baker ( 1978 ), the steady creep with fine-grained ices is controlled by diffusional processes whereas that with coarse-grained ices is controlled by the mobility of dislocations in their glide planes. If, as shown above, Nabarro-Herring diffusional creep seems to be occurring for fine-grained ices and low stresses, it is not the case for a glidecontrolled creep increasing with crystal size (Duval, 1973).

The present study was initiated in order to verify the influence of ice-crystal size on steady creep, using artificial and natural ices. 

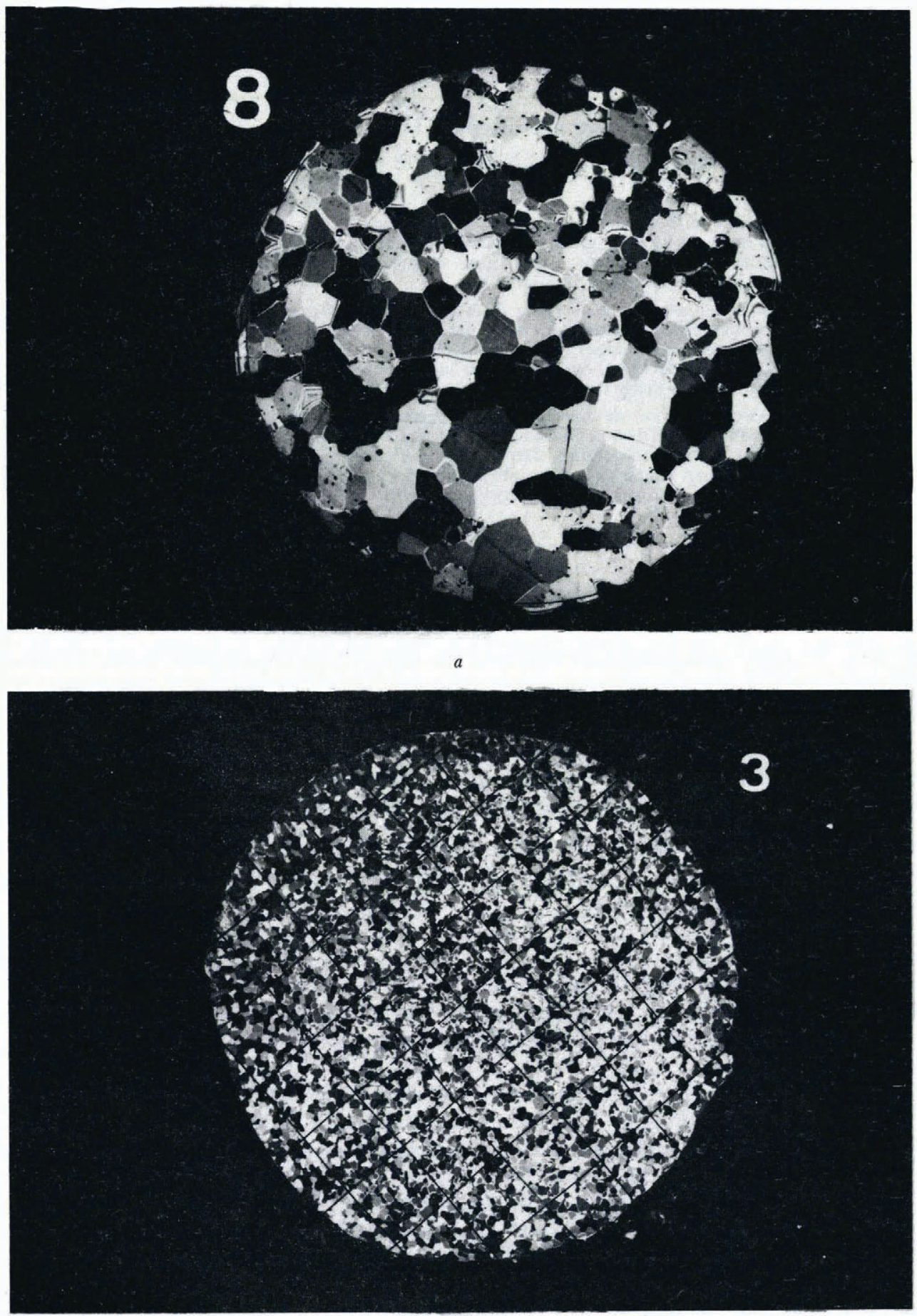

$b$

Fig. I. Thin-section photographs of two typical artificial ice samples: (a) $A_{2}$ full size, $(b) A_{4}$ full size. 


\section{EXPERIMENTAL METHODS}

The artificial ice samples were prepared by packing sieved ice grains, made from frozen de-ionized distilled water, into a cylindrical mould which was $80 \mathrm{~mm}$ in diameter and about I $60 \mathrm{~mm}$ long. The mould was de-aerated and the void spaces were filled by admitting air-free water at $0^{\circ} \mathrm{C}$. Fine-grained samples were frozen in a cold room at $-15^{\circ} \mathrm{C}$ and coarse-grained samples in a cold room kept at $-\mathbf{I} .0^{\circ} \mathrm{C}$. Several days were necessary to freeze samples completely at $-\mathrm{I} . \mathrm{O}^{\circ} \mathrm{C}$. Samples thus prepared were almost free of bubbles. Density was about $0.91 \mathrm{Mg} \mathrm{m}^{-3}$ for all the samples.

At each extremity of the samples, a thin section was cut perpendicular to the long axis before testing. Sample length for testing was about $120 \mathrm{~mm}$ and diameter $80 \mathrm{~mm}$. Average grain-size was determined from enlarged photographs of thin sections. Crystal size from thin sections cut from both ends of samples varied less than o. I mm for fine-grained ices (grainsize below $2 \mathrm{~mm}$ ), but the crystal-size variation could attain $\mathrm{I} \mathrm{mm}$ for coarse-grained ices (grain-size of about $7 \mathrm{~mm}$ ). Figure I shows two thin-section photographs of samples with different grain size.

Isotropy of all the samples was verified by determining $c$-axis orientation of crystals. It was also verified by cutting sections after testing that no grain-size variations had occurred during deformation.

Natural ice samples come from a drilling carried out near Dio station (Antarctica). Temperature of the ice was $-4^{\circ} \mathrm{C}$ in the upper layers and reached $-7^{\circ} \mathrm{C}$ at the bottom . Crystal size was always greater than $4 \mathrm{~mm}$. Fabrics of these samples were determined before testing. Isotropy was verified for the sample $\mathrm{D}_{4} 6$ (depth: $46 \mathrm{~m}$ ) but a slight anisotropy was found for the other samples.

A constant uniaxial load was applied parallel to the long axis of samples with the apparatus used by Duval ([1977]) in a cold room kept at $(-4.6 \pm 0 . \mathrm{I})^{\circ} \mathrm{C}$ or at $(-7 . \mathrm{I} \pm 0 . \mathrm{I})^{\circ} \mathrm{C}$. Strain was measured as a function of time by a linear variable differential transformer transducer (L.V.D.T.) and the output was recorded continuously. Strain of about $2 \times 10^{-5}$ could be measured. Stress was always kept at values not very different from $0.5 \mathrm{MN} / \mathrm{m}^{2}$.

\section{Results}

Typical creep curves obtained with two artificial ices are shown in Figure 2. It can be seen that transient creep is more important for the coarse-grained ice than for the fine-grained ice. By assuming that creep curves fit the Andrade's law:

$$
\epsilon=\epsilon_{0}+\beta t^{\frac{1}{3}}+\gamma t,
$$

where $\epsilon_{0}$ is the instantaneous strain, and $\beta$ and $\gamma$ constants, the tangent at the origin of the creep curves plotted against $t^{\frac{1}{3}}$ represents the transient creep. Figure 3 shows the transient creep for artificial ices. Broadly the Andrade creep increases with grain-size. This result is in accordance with that given by Duval (1973).

Results of tests on artificial and natural ices are presented in Table I. We have quoted on the one hand the measured strain-rates at the end of experiments and on the other hand the strain-rates calculated by taking into account the Andrade creep. The calculated strain-rates are always smaller than the measured strain-rates. So, it is possible that secondary creep was not attained in the experiments. Indeed the total strain ranged only from 0.5 to $\mathrm{I} \%$. But no measurable variation of strain-rate was observed in a time interval of about $24 \mathrm{~h}$.

Figure 4 shows the normalized strain-rates versus average grain-size for both artificial and natural ice samples. It appears that creep-rate does not show a significant variation with grainsize. On the other hand, the creep-rates of natural ice samples are of the same order as those of artificial ice samples. The creep-rate of the isotropic sample $\mathrm{D}_{4} 6$ is smaller than those of the other natural samples. 


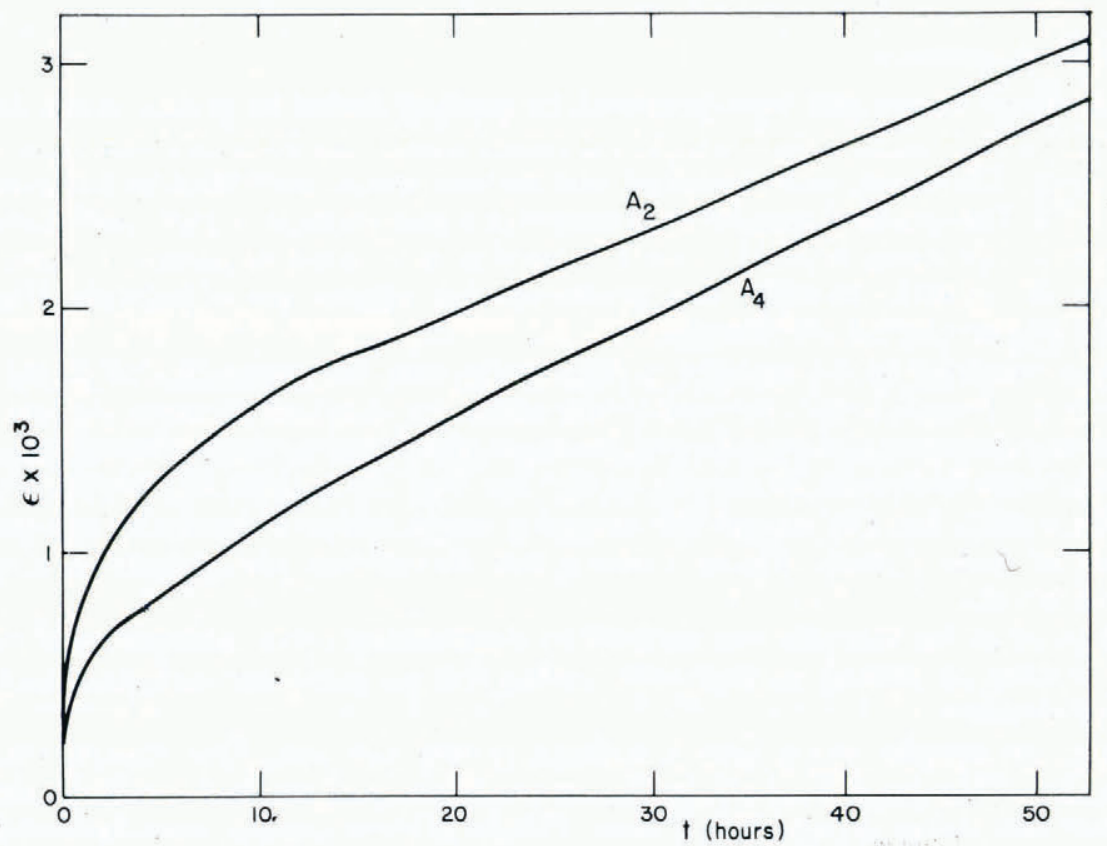

Fig. 2. Typical creep curves for two artificial ice samples. Compression stress: $0.5 M \mathcal{N} m^{-2}$, temperature $T=-7.2 \pm 0.1^{\circ} \mathrm{C}$.

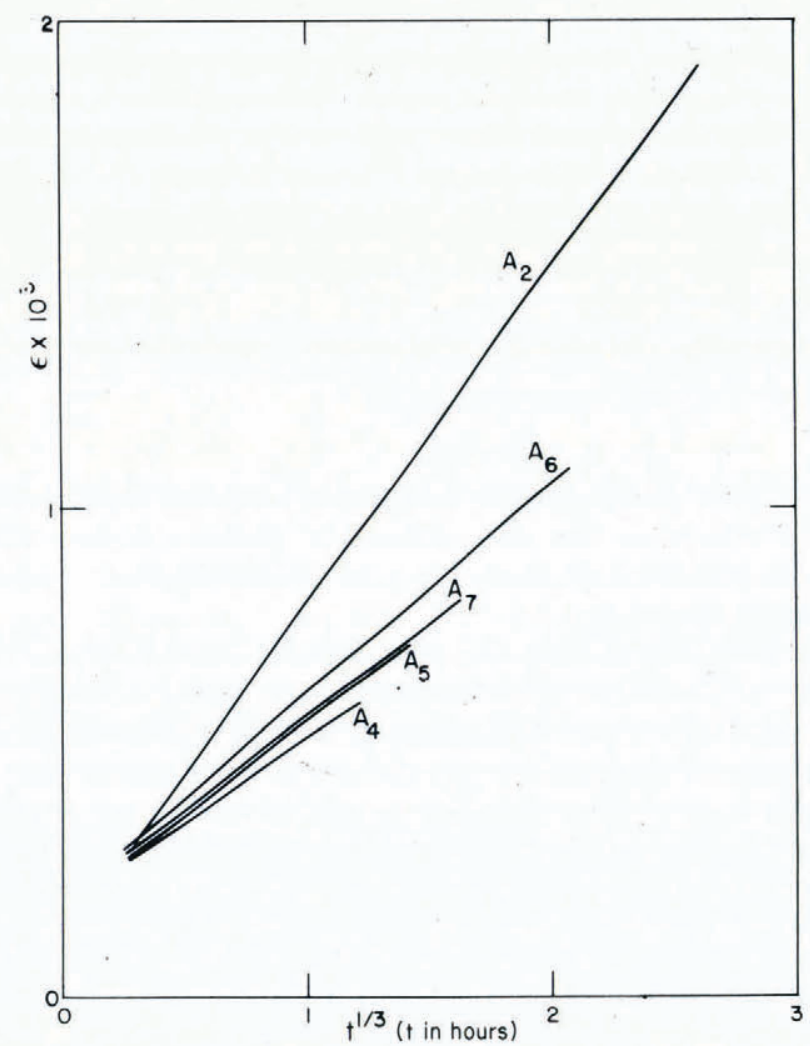

Fig. 3. Andrade transient creep plotted against $t^{\mathrm{t}}$ for various artificial samples. The compression stress varied between $0.4^{8}$ $M \mathcal{N} m^{-2}$ for sample $A_{5}$ and $0.5 M \mathcal{N} m^{-2}$ for samples $A_{2}$ and $A_{4}$. Temperature $T=-7.2 \pm 0.1^{\circ} \mathrm{C}$. 
TABle I. Summary of experimental Results

\begin{tabular}{|c|c|c|c|c|c|c|c|c|}
\hline Sample & $\begin{array}{l}\text { Initial } \\
\text { length } \\
\mathrm{mm}\end{array}$ & $\begin{array}{l}\text { Applied } \\
\text { stress } \\
\mathrm{MN} \mathrm{m}^{-2}\end{array}$ & $\begin{array}{c}\text { Duration } \\
\text { of } \\
\text { experiments } \\
\mathrm{h}\end{array}$ & $\begin{array}{l}\text { Average } \\
\text { grain- } \\
\text { size } \\
\mathrm{mm}\end{array}$ & $\begin{array}{c}\text { Temperature } \\
{ }^{\circ} \mathrm{C}\end{array}$ & $\begin{array}{c}\text { Minimum } \\
\text { measured } \\
\text { strain-rate } \\
\text { year-1 }^{-1}\end{array}$ & $\begin{array}{c}\text { Calculated } \\
\text { strain-rate } \\
\text { year-1 }\end{array}$ & $\begin{array}{c}\text { Normalized } \\
\text { strain-rate } \\
\text { year }^{-1}\end{array}$ \\
\hline $\mathrm{A}_{\mathrm{I}}$ & II 9 & 0.50 & 120 & 1.80 & -4.6 & 0.594 & - & $0.37 \mathrm{I}$ \\
\hline Dgo & 120 & 0.50 & 72 & 9.80 & -4.6 & 0.920 & - & 0.570 \\
\hline $\mathrm{D}_{46}$ & 120 & $0.4^{8}$ & 78 & 4.60 & -7.0 & 0.287 & - & 0.310 \\
\hline $\mathrm{A}_{2}$ & 120 & 0.50 & $5^{6}$ & 5.06 & -7.0 & 0.270 & 0.124 & 0.259 \\
\hline $\mathrm{D}_{72}$ & 120 & 0.49 & 100 & 3.96 & -7.2 & 0.403 & - & 0.428 \\
\hline $\mathrm{A}_{3}$ & 120 & 0.48 & 95 & I.07 & -7.2 & 0.310 & 0.240 & $0.35^{\circ}$ \\
\hline $\mathrm{A}_{4}$ & II 7 & 0.50 & 76 & I.10 & -7.2 & 0.366 & - & 0.366 \\
\hline $\mathrm{A}_{5}$ & 120 & 0.48 & 105 & 1.40 & -7.2 & 0.257 & 0.178 & 0.290 \\
\hline Dilo & 120 & 0.48 & 126 & 8.90 & -7.0 & $0.35^{\circ}$ & - & 0.379 \\
\hline A6 & II 9 & 0.49 & 150 & 7.00 & -7.2 & 0.129 & 0.089 & 0.137 \\
\hline $\mathrm{A}_{7}$ & 118 & 0.49 & 75 & 1.88 & -7.2 & 0.233 & - & 0.247 \\
\hline
\end{tabular}

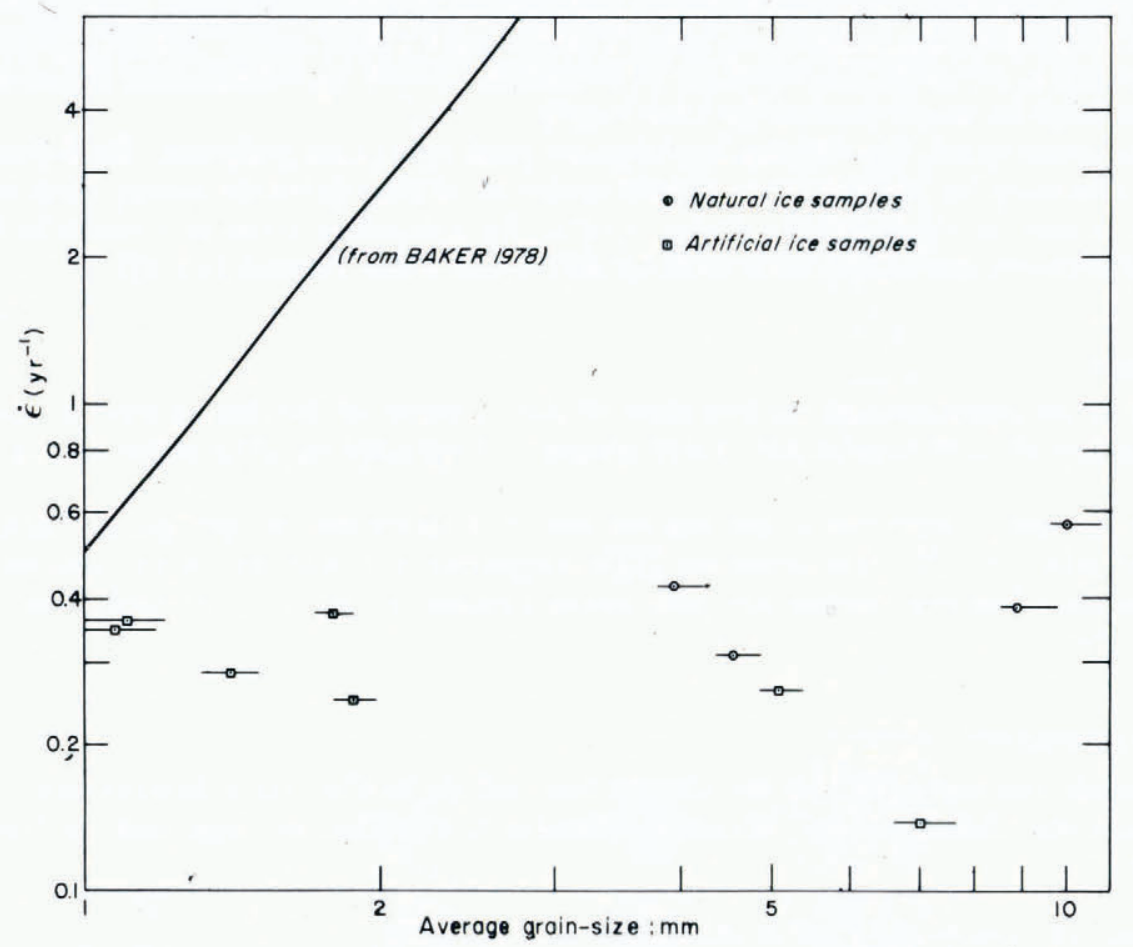

Fig. 4. Normalized minimum creep-rate versus average grain-size for both artificial and natural ice samples. Artificial ice samples are noted by the letter " $A$ " and natural ice samples by the letter " $D$ ". Creep-rates were normalized to a stress of $0.5 \mathrm{MN} \mathrm{m} \mathrm{m}^{-2}$ from Equation ( $\mathrm{I}$ ) with $n=3$ and to a temperature of $-7.2^{\circ} \mathrm{C}$ with an activation energy of $I 2 \mathrm{I} \mathrm{kJ} \mathrm{mol}$-1. The line is from Baker $\left(197^{8}\right)$, but normalized at $0.5 \mathrm{MN} \mathrm{m} \mathrm{m}^{-2}$ and $T=-7.2^{\circ} \mathrm{C}$ with an activation energy of $88 \mathrm{~kJ}$ $\mathrm{mol}^{-1}$. Samples $A_{1}$ (average grain-size: $1.80 \mathrm{~mm}$ ) and $D_{90}$ (average grain-size: $9.80 \mathrm{~mm}$ ) were tested at $-4.6^{\circ} \mathrm{C}$, whereas all the others were tested between $-7.0^{\circ} \mathrm{C}$ and $-7.2^{\circ} \mathrm{C}$.

\section{Discussion}

These results appear to conflict with those given by Baker (1978). Indeed, the measured creep-rates did not increase with crystal size above i $\mathrm{mm}$. It is important to note that, in spite of stresses and temperature being of the same order in the two studies, creep-rates quoted in Table I and in Figure 4 of this study are always smaller than those measured by Baker (Fig. 4). In Baker's study the total strain ranged from 5 to $15 \%$ whereas it ranged only from 
0.5 to $\mathrm{I} \%$ in the present study. If we assume that secondary creep was not attained in our experiments, the differences of creep-rate between the two studies become still more important. If, as Figure 3 seems to show, transient creep increases with grain-size, it is possible that secondary creep-rates slightly decrease with grain size.

It is difficult to give explanations for these conflicting results. The high creep-rates found by Baker ( 1978 ) could be explained by the formation of cracks in his small samples owing to a non-uniform distribution of stress. Strain steps were not observed in this study.

In metals, there is no experimental confirmation of the increase of secondary creep-rate with grain size (Barrett and others, 1967). At high temperature, sub-boundaries formed during transient creep may act as barriers to dislocation motion like grain boundaries. But grain boundaries or sub-boundaries may also act as sources of dislocations. According to Hondoh and Higashi (1978), lattice dislocations could be generated from the lines of intersec.ion of boundaries and the sample surface. Recent studies have shown the influence of sub-grains on the secondary creep-rate for polycrystalline sodium chloride and single-crystal silver chloride (Robinson and others, 1974; Pontikis and Poirier, 1975). Sub-boundaries have been observed in ice single crystals from Mendenhall Glacier by Fukuda and Higashi (1969) and in artificial ice single crystals by Maï (1976).

On the other hand, the relationship between yield stress and grain-size (Hall-Petch-type relation) discussed by Baker (1978) cannot easily be extrapolated for steady state in creep tests. Moreover, at temperatures above $-10^{\circ} \mathrm{C}$, the secondary creep-rate seems to be controlled by recovery processes rather than by dislocation glide (Duval, [1977]).

\section{Conclusion}

There is no experimental confirmation of the increase of the permanent creep-rate of polycrystalline ice with crystal size. Only transient creep appears to be influenced by crystal size.

However, more laboratory creep tests are required before we can extrapolate these results to low temperatures. For temperate ice, high creep-rates are expected for fine-grained ices if the correlation between crystal size and water content is real (Vallon and others, 1976; Duval, 1977).

\section{Acknowledgements}

This study was supported by the Centre National de la Recherche Scientifique (A.T.P., high-temperature deformation). We are indebted to A. Chaillou for suggestions and technical assistance.

\section{MS. received 25 January 1979 and in revised form 26 April 1979}

\section{REFERENCES}

Baker, R. W. 1978. The influence of ice-crystal size on creep. Fournal of Glaciology, Vol. 21, No. 85, p. 485-500.

Barrett, C. R., and others. 1967. Effect of grain size and annealing treatment on steady state creep of copper, by C. R. Barrett, J. L. Lytton, and O. D. Sherby. Transactions of the Metallurgical Society of the A.I.M.E., Vol. 239, No. 2, p. $170-80$.

Colbeck, S. C., and Evans, R. J. 1973. A flow law for temperate glacier ice. Journal of Glaciology, Vol. 12, No. 64, p. $71-86$.

Duval, P. 1973. Fluage de la glace polycristalline pour les faibles contraintes. Comptes Rendus Hebdomadaires des Séances de l'Académie des Sciences (Paris), Sér. A, Tom. 277, No. 14, p. 703-06.

Duval, P. [1977.] Lois du fluage transitoire ou permanent de la glace polycristalline pour divers états de contrainte. Annales de Géophysique, Tom. 32, No. 4, 1976, p. 335-50. 
Duval, P. 1977. The role of the water content on the creep rate of polycrystalline ice. [Union Géodésique et Géophysique Internationale. Association Internationale des Sciences Hydrologiques. Commission des Neiges et Glaces.] Symposium. Isotopes et impuretés dans les neiges et glaces. Actes du colloque de Grenoble, août/septembre 1975, p. 29-33. (IAHS-AISH Publication No. I 18 .)

Fukuda, A., and Higashi, A. 1969 . X-ray diffraction topographic studies of dislocations in natural large ice single crystals. Fapanese Fournal of Applied Physics, Vol. 8, No. 8, p. 993-99.

Goodman, D. J. 1978. (In "Discussion" of Baker (1978), p. 497-50o.)

Goodman, D. J. Unpublished. Creep and fracture of ice and surface strain measurements on glaciers and sea ice. [Ph.D. thesis, University of Cambridge, I977.]

Hondoh, T., and Higashi, A. 1978. X-ray diffraction topographic observations of the large-angle grain boundary in ice under deformation. Fournal of Glaciology, Vol. 21 , No. 85 , p. 629-38.

Maï, C. 1976 . Étude par topographie X du comportement dynamique des dislocations dans la glace Ih. Comptes Rendus Hebdomadaires des Séances de l'Académie des Sciences (Paris), Sér. B, Tom. 282, No. 22, p. 515-18.

Mellor, M., and Testa, R. 1969. Creep of ice under low stress. Fournal of Glaciology, Vol. 8, No. 52, p. $147-52$.

Pontikis, V., and Poirier, J. P. 1 975 . Phenomenological and structural analysis of recovery-controlled creep, with special reference to creep of single-crystal silver chloride. Philosophical Magazine, Eighth Ser., Vol. 32, No. 3, p. $577-92$.

Robinson, S. L., and others. 1974. Activation energy and subgrain size-creep rate relations in sodium chloride, by S. L. Robinson, P. M. B. Burke, and O. D. Sherby. Philosophical Magazine, Eighth Ser., Vol. 29, No. 2,
p. 423-27.

Vallon, M., and others. 1976. Study of an ice core to the bedrock in the accumulation zone of an Alpine glacier by M. Vallon, J.-R. Petit, and B. Fabre. Journal of Glaciology, Vol. 17, No. 75, p. 13-28. 